\title{
(Mis)Interpreting Vaclav Havel: Conviction and Responsibility in Post-Communist Politics
}

\author{
Peter Russell \\ Independent Researcher \\ peter.a.russell@gmail.com
}

\begin{abstract}
This article examines Vaclav Havel's alleged failure to understand the need for a "realistic" approach to post-communist politics and the criticisms of his insistence on retaining his principles and focus on morality in his conduct as president of Czechoslovakia in the early 1990s. It argues that these criticisms do not stand up against an examination either of how Havel actually behaved in this period or of his writings and statements concerning his actions and beliefs, that they are based on a misunderstanding of what Havel hoped to achieve as president, and make unjustified assumptions concerning the desirability of Western political and economic systems in the early post-communist period. This article seeks to clarify Havel's perception of his role as president, of the goals of the revolution and what he personally hoped to achieve, and his understanding of the opportunity that had been offered to Czechoslovakia by the fall of the communist government.
\end{abstract}

Key words: anti-politics; Czechoslovakia; Havel; morality; politics; post-communism

\section{Introduction}

Over the course of a lifetime of dissident activity and opposition to the communist state in Czechoslovakia, Vaclav Havel developed, tested, and refined his ideas about the proper relationship between morality and politics. By the late 1980s, his thinking on these matters, and his determined adherence to his convictions and beliefs in the face of sustained harassment and repeated imprisonment by the Soviet-backed government, had won him respect and admiration from people around the world. It was this respect and admiration which led to his sudden, unexpected, and highly improbable election in December 1989 to the office of President of Czechoslovakia, something which Havel himself had thought was 'out of the question' since the parliament which elected him was still dominated by 'the previous regime'. ${ }^{1}$ Five years later, Havel summed up his conclusions about morality and politics in one short phrase: 'Morality is omnipresent, and so is politics, and politics that dissociates itself from morality is simply bad politics'. ${ }^{2}$

\footnotetext{
${ }^{1} \mathrm{~V}$. Havel, Address to a Joint Session of the US Congress, 21 February 1990,

<http://old.hrad.cz/president/Havel/speeches/index_uk.html>, accessed on 4 February 2013.

${ }^{2}$ V. Havel, Catalonia International Prize Speech, 11 May 1995,

<http://old.hrad.cz/president/Havel/speeches/index_uk.html>, accessed on 4 February 2013.
} 
In making that statement, Havel demonstrated a continuity in his thinking that had survived the tumultuous changes that both he and his country went through in the early 1990 s. But in ascending 'from the Prison to the Castle' 3 in December 1989, Havel was forced to reconcile his ideas and his ideals about politics and morality, developed in opposition, with the practice of being a working politician, revolutionary, and national leader in circumstances of extreme uncertainty and fluidity. Havel's response to his new circumstances and responsibilities was entirely consistent with his past practices and beliefs: he continued to insist that morality had to be the basis of his beliefs, decisions, and actions as Czechoslovakia's president just as it had been during his life as a dissident. 'The main problem faced by the country', he said a few days after becoming president, was the 'contaminated moral atmosphere'. But, he added, there was a solution to this problem. His revered predecessor Tomas Masaryk, president of Czechoslovakia from 1918 to 1935, had 'based his politics on morality', and it was time, 'in a new way, to restore this concept of politics'.4

Havel's insistence on this point has been derided as being counterproductive, naïve, and even potentially dangerous for the future of his country. Domestic and foreign critics of Havel's performance as president, and of developments in post-communist Czechoslovakia more widely, have argued that he should have adopted a new perspective, one based on the concept of politics as a matter of interests rather than morality. He should have set aside his principles in order to play the political game as it is normally played in the West, given up his insistence on remaining an 'amateur' politician, and become a 'professional'.5 But the arguments that Havel failed to understand or simply refused to adopt such a supposedly "realistic" approach to postcommunist politics, that he did not appreciate the importance of institutionbuilding and the need for "professional" interest-based politics, do not stand up against an examination either of how Havel actually behaved in this period or of his writings and statements concerning his actions and beliefs. ${ }^{6}$ This article argues that there are two major flaws in such arguments: first, that they are based largely on a fundamental incomprehension of exactly what Havel personally was hoping to achieve in his role as President of his country and, second, that they make unjustified assumptions concerning the innate superiority and appeal of the political and economic systems found in the West and about their status as the inevitable, logical destination of the Velvet Revolution. This article seeks to clarify Havel's perception of his role as president, of the goals of the revolution and what he personally hoped to achieve, and his understanding of the opportunity that had been offered to Czechoslovakia by the fall of the communist government.

\footnotetext{
3 I. K. Naffziger, 'From the Prison to the Castle: The Legacy of Vaclav Havel', Hoover Digest 2003 No. 1 (January 30, 2003), <http://www.hoover.org/publications/hoover-digest/article/6684>, accessed 4 February 2013.

4 V. Havel, New Year's Address to the Nation, 1 January 1990,

<http://old.hrad.cz/president/Havel/speeches/index_uk.html>, accessed on 4 February 2013.

5 Michael Simmons, The Reluctant President: A Political Life of Vaclav Havel, London, Methuen, 1991, pp. 191-2.

${ }^{6}$ There are of course those who argue that Havel demonstrated considerable political skill and ability; see, inter alia, Timothy J. Madigan, 'Transcending Havel', Free Inquiry Fall, 1998, p. 9; Delia Popescu, Political Action in Vaclav Havel's Thought: the Responsibility of Resistance, Lexington Books, Lanham, 2012, p. 14.
} 


\section{Conviction or Responsibility?}

One of Havel's best-known ideas was what he called 'anti-political politics', a concept which he developed as a dissident and described in his 1984 essay 'Politics and Conscience'. Anti-political politics was politics not as the technology of power and manipulation, of cybernetic rule over humans or as the art of the utilitarian, but politics as one of the ways of seeking and achieving meaningful lives, of protecting them and serving them ... politics as practical morality, as service to the truth, as essentially human and humanly measured care for our fellow humans. 7

Anti-political politics, in Havel's conception, involved what April Carter characterises as a 'distrust of party politics' and sought 'an alternative to the practice of Western liberal democracy'. ${ }^{8}$ When asked in the first few months of his presidency about the 'secret of politics', Havel replied 'Write your own speeches and express hard truths in a polite way'.9 Reflecting on his thinking after two years of high office, Havel confirmed the durability of the ideas he developed in 'Politics and Conscience' when he wrote that Genuine politics is simply a matter of serving those around us: serving the community, and serving those who will come after us. Its deepest roots are moral because it is a responsibility, expressed through action, to and for the whole. ${ }^{10}$

Havel's decision to apply these dissident-era principles to his conduct as president has often been taken as evidence that he did not properly understand his new environment, circumstances, and responsibilities. Ralf Dahrendorf, for example, suggests that the appropriate choice for Havel (or indeed anyone else) would have been to apply Max Weber's distinction between 'an "ethics of conviction" and an "ethics of responsibility" ... The former', he writes, 'espouses absolute values; it is the morality of saints. The latter recognizes the complexity of means-ends relationships; it is the ethics of politicians'.11 In spite of his stated admiration for Havel, Dahrendorf clearly believes that he was unable to make the shift from the mode of conviction to the mode of responsibility, and that his insistence on absolute values and beliefs, while appropriate or even necessary when used in opposition to totalitarianism, became an obstacle in the context of a pluralistic democratic society. Aviezer Tucker takes up the same theme, claiming that Havel's 'perfectionist virtue ethics of conviction...did not fit his new responsibilities'.12 From this perspective, Havel was essentially a prisoner of his dissident viewpoint, unable or unwilling to properly consider the possibility that he might need to change his approach and attitudes to suit the changed

\footnotetext{
7 V. Havel, 'Politics and Conscience', February 1984,

$<$ http://www.vaclavhavel.cz/showtrans.php?cat=clanky\&val=73_aj_clanky.html\&typ=HTML>, accessed on 4 February 2013.

8 A. Carter, 'Vaclav Havel: Civil Society, Citizenship and Democracy', in A. Carter, G. Stokes,(eds.), Liberal Democracy and its Critics, Cambridge, Polity Press, 1998, pp. 58-59.

9 P. C. Newman, 'Saluting the playwright who became president', Maclean's, Vol. 111, No. 33, 1998, p. 52. ${ }^{10}$ V. Havel, Summer Meditations on Politics, Morality and Civility in a Time of Transition, transl. Paul Wilson, London, Faber and Faber, 1992, pp. 5-6.

${ }_{11}^{11}$. Dahrendorf, After 1989: Morals, Revolution and Civil Society, New York, St. Martin's Press, 1997, p. 52.

${ }_{12}$ A. Tucker, The Philosophy and Politics of Czech Dissidence from Patocka to Havel, Pittsburgh, University of Pittsburgh Press, 2000, p. 17.
} 
circumstances in which he found himself. There is, to be sure, some evidence for this to be found in Havel's own words. In 1992, for example, he wrote that, although [t]here may be some who won't believe me ... in my second term as president in a land full of problems that presidents in stable countries never even dream of, I can safely say that I have not been compelled to recant anything of what I wrote earlier, or to change my mind about anything. It may seem incredible, but it is so: not only have I not had to change my mind, but my opinions have been confirmed. ${ }^{13}$

In 2007, having spent time reading over old memos in the preparation of his book To the Castle and Back, Havel 'realize[d] - and this is encouraging that in fact I have always thought more or less the same way and worked ... to achieve the same things'. ${ }^{14}$ And for some, this was a positive thing: the playwright Friedrich Durrenmatt wrote in an open letter to Havel in December 1990 that his 'mission as President is the same as the mission of Vaclav Havel, dissident'. ${ }^{15}$

However, for his critics, Havel's alleged lack of understanding of his proper role was supposedly demonstrated in a variety of ways. One of the most prominent accusations was that Havel lacked what Tucker describes as a "basic ... understanding of the significance of institutions and the rule of law" which proved disastrous to the development of the post-communist Czechoslovak state and which ultimately led to the disintegration of the country in $1993 .{ }^{16}$ Institutions, in this context, mean virtually everything from the constitution to political parties to parliamentary procedure to a functioning free press. Juan J. Linz and Alfred Stepan consider Havel's decision 'not to try to form a statewide party' and his failure to 'ask ... the existing Federal Assembly to modify the constitution shortly after he was elected president' as key elements in Czechoslovakia's eventual dissolution. ${ }^{17}$

Vaclav Zak, in his analysis of the 'institutional foundations' of Czechoslovakia's dissolution, argues in general terms that since '[t]he coordination and pre-negotiation of political decisions that normally take place in political parties was weakened, and sometimes eliminated entirely ... [the] coordination between institutions suffered' because few of the new leaders of the country 'understood the necessity of pre-negotiating decisions, vital for formal relations between institutional representatives'.18 More specifically, he argues that Havel's proposals concerning changing the country's official name (dropping the word "Socialist") failed because he 'assumed that the deputies would pass his proposals on the spot. ... he had not changed his conceptions about the leadership of an institution that is joined with other institutions by a range of procedural rules' ${ }^{19}$

\footnotetext{
${ }_{13}$ Havel, Summer Meditations, op. cit., p. 10.

14 V. Havel, To the Castle and Back, New York, Alfred A. Knopf, 2007, p. 35.

15 Quoted in Simmons, op. cit., p. 217.

16 Tucker, op. cit., pp. 17, 205.

${ }_{17}$ J. J. Linz and A. Stepan, Problems of Democratic Transition and Consolidation: Southern Europe, South America, and Post-Communist Europe, Baltimore, The Johns Hopkins University Press, 1996, p. 331. For a broader discussion of all the elements they see as involved in Czechoslovakia's breakup, see pp. 329-333.

${ }^{18}$ V. Zak, 'The Velvet Divorce - Institutional Foundations', in Jiri Musil, (ed.), The End of

Czechoslovakia, Budapest, Central European University Press, 1995, p. 249.

19 Ibid., p. 250. For Havel's perspective on this, see Summer Meditations, op. cit., p. 23; To the Castle and Back, op. cit., pp. 122-124. The criticisms of Havel in relation to the breakup of Czechoslovakia seem
} 
The argument that the "ethics of responsibility" were necessary (or at least more appropriate) in the post-Communist period is a perfectly legitimate one, but the contention that Havel was unable as president to adapt to the changed circumstances and adhered blindly to the "ethics of conviction" does not stand up to an examination of the evidence. Certainly there was a period of learning and adaptation after his ascent from prison to the Castle, and there were frequent missteps and miscalculations. The vast differences between being a persecuted dissident and being president of Czechoslovakia made this inevitable. To expect a flawless transition from the one existence to the other would indeed be unrealistic, particularly if one concedes that, as Martin Krygier points out, the early post-communist period consisted of 'a series of unpredicted and unprecedented social experiments, on which there were no experts'. ${ }^{20}$ Havel himself observed that while he tried to be 'sober, down to earth, and cautious', he did sometimes 'succumb ... to the heady atmosphere of the time' and had 'done things that a year later I would not have done and could not - and rightly so - have gotten away with'. ${ }^{21}$

Havel was well aware of the potential pitfalls of his 'anti-political' approach to morality and politics, but he was not interested in presenting comforting fictions or in making political and social realities more palatable and less difficult than he felt they actually were. 'I assume,' he said to his audience in his 1990 New Year's Address to the Nation, that 'you did not propose me for this office so that I ... would lie to you'. ${ }^{22}$ So he began his presidential career by stating frankly the bald facts of the situation in Czechoslovakia as it appeared to him:

Our country is not flourishing. The enormous creative and spiritual potential of our nations is not being used sensibly. Entire branches of industry are producing goods that are of no interest to anyone, while we are lacking the things we need. A state which calls itself a workers' state humiliates and exploits workers. Our obsolete economy is wasting the little energy we have available. A country that once could be proud of the educational level of its citizens spends so little on education that it ranks today as seventy-second in the world. We have polluted the soil, rivers and forests bequeathed to us by our ancestors, and we have today the most contaminated environment in Europe. Adults in our country die earlier than in most other European countries. 23

Speaking in this manner fit comfortably within Havel's dissident-era ideas about "living in truth" and the importance of 'reject[ing] the ritual and break[ing] the rules of the game' to 'discover once more ... [one's] suppressed

in many respects to contradict each other. On the one hand, Linz and Stepan's argument almost suggests too great a respect for the institutions of the state as dictated by the communist-era constitution that was still in place. The majority of other critics argue that Havel simply didn't appreciate the importance of institutions at all.

${ }^{20}$ M. Krygier, 'The Quality of Civility: Post-Anti-Communist Thoughts on Civil Society and the Rule of Law', in András Sajó, (ed.), Out of and Into Authoritarian Law, The Hague, Kluwer Law International, 2003 , p. 222.

${ }^{21}$ Havel, To the Castle and Back, op. cit., p. 59.

${ }^{22}$ V. Havel, New Year's Address to the Nation 1990, op. cit.

23 Ibid. 
identity and dignity' and 'give [one's] freedom a concrete significance'. ${ }^{24}$ It was certainly a dramatic change from the approach of his Communist predecessors, but Western audiences are not terribly accustomed to such candour from their elected officials either.

At the same time, Havel fully understood the need at times for subtlety, nuance, and diplomacy: 'in politics, as elsewhere in life, it is impossible and pointless to say everything, all at once, to just anyone. But that does not mean having to lie'.25 What was needed, he argued, was 'tact, the proper instincts, and good taste' to know what to say, when, to whom, and how. ${ }^{26}$ For his 1990 New Year's Address, he actively decided that brutal frankness was appropriate and necessary; he did not somehow fail to understand that politicians are not supposed to speak in such terms. But he approached other issues very differently. For instance, it has become a sort of common knowledge that, as one interviewer put it in 2009, 'at the beginning of [his] presidency [Havel] apologized for the displacement of Germans' from the Sudetenland after World War II. ${ }^{27}$ Havel, according to another commentator, 'believed that politics and foreign policy could only be conducted with outstanding moral wrongs righted, which included an apology for the expulsion'. ${ }^{28}$ But as Havel himself pointed out, 'it's not exactly right' to say that he 'apologized for the displacement'; what he said was that 'we should somehow apologize'. ${ }^{29} \mathrm{He}$ later wrote that 'I didn't offer an apology, either on my own behalf or on the state's behalf. I merely said that a Czechoslovak apology would be a good thing'. ${ }^{30}$ The distinction has been lost on many, but it was an effective and diplomatic way to bring the subject up without officially addressing it as president.

Havel's reaction to the situation of Jan Kavan in 1991 and 1992 also demonstrated his ability to be nuanced and thoughtful in his political behaviour as president. Kavan, at the time a member of parliament and a long-time dissident himself (it was through his publishing company, Palach Press, that much of Havel's work was first made available in the West), was publicly accused in March 1991 of being a communist-era informant of the communist secret police, the StB. Ultimately, he became a target of the lustration law passed in October of the same year. ${ }^{31}$ Kavan's background and

\footnotetext{
${ }^{24}$ V. Havel, 'The Power of the Powerless', October 1978,

http://www.vaclavhavel.cz/showtrans.php?cat=clanky\&val=72_aj_clanky.html\&typ=HTML, accessed on 4 February 2013.

25 Havel, Summer Meditations, op. cit., pp. 10-11.

${ }^{26}$ Ibid., p. 11.

27 'Still Searching for Answers: A discussion with Vaclav Havel and Richard von Weizsäcker', German Council on Foreign Relations, 1 November 2009, https://ip-journal.dgap.org/en/ip-journal/topics/stillsearching-answers, accessed on 4 February 2013.

${ }^{28}$ R. Fawn, 'Symbolism in the Diplomacy of Czech President Vaclav Havel', East European Quarterly XXXIII, No. 1 (March 1999), p. 5. Jan Pauer describes it as a 'publicly expressed ... moral apology'; 'Moral Political Dissent in German-Czech Relations', Czech Sociological Review, 1998, Vol. 6 (No. 2), p. 173.

29 'Still Searching for Answers...', op. cit.

$3^{\circ}$ Havel, To the Castle and Back, op. cit., p. 139. See also Vaclav Havel, The Visit of German President Richard von Weizsacker, March 15, 1990, http://old.hrad.cz/president/Havel/speeches/index_uk.html, accessed on 4 February 2013; Keane, op. cit., pp. 467-469.

${ }^{31}$ For more on the Czech lustration law, see A. Innes, Czechoslovakia: The Short Goodbye, New Haven, London: Yale University Press, 2001, pp. 90-91; Keane, op. cit., pp. 428-433, D. W. Stewart \& C. V. Stewart (1995): 'Lustration in Poland and the former Czechoslovakia: a study in decommunization', International Journal of Public Administration, 18:6 (1995), pp. 889-906; R. David, 'Lustration Laws in
} 
prominence meant that the case was widely reported internationally, and his past association with Havel meant that the president's actions in the case were the subject of considerable attention and discussion. Given Havel's public opposition to lustration, which he feared was becoming little more than 'lawless revenge and witch-hunts', $3^{2}$ and his personal associations with Kavan, many observers felt that he could not possibly 'remain silent now'.33 But Havel did not take a strong public position concerning the attacks on Kavan. Instead, he met with Kavan and told him that, while he was certain the allegations were false, the issue was too politicized for him to take a public stance on it. The political repercussions would be too great, given the high emotions stirred up by the case. 34 Keane portrays this as a "farewell to his old noble habit of drawing black-and-white distinctions between "truth" and "lies" and as a cynical means of securing his own position and power in the state. 35 It could equally be seen as recognition that the "ethics of conviction" were in fact not always appropriate in the new Czechoslovakia.

Far from being trapped in his past, the Kavan episode and others demonstrate that Havel was able and willing to apply the "ethics of responsibility" when he believed it was called for. $3^{6}$ Of course, a crucial element in the debate over how to assess whether Havel's actions stemmed from 'conviction' or 'responsibility' is the fact that there is no clear delineation between the two concepts. From Havel's perspective, indeed, there may have been no dividing line at all, with 'conviction' being the source of goals and intentions and 'responsibility' being the ways and means to achieve the intended ends. For the purposes of this argument, it is perhaps sufficient to point out that the deciding whether or not Havel was unable or unwilling to apply the 'ethics of responsibility' is a highly subjective process which does not yield the definite answers offered by Havel's critics. Moreover, as the next section argues, this process is greatly affected by what one thinks the goals and intentions are in any given situation.

\section{The Teleology of Transition}

Havel's critics often do not appear to concede the experimental nature of the period of transition from communism to post-communism, 37 which inevitably complicates the debate over the ethics which he employed as president. Instead, many observers and commentators, both at the time and since, see the period not as one of experimentation but as one of transition to a predetermined goal. From this perspective, the intended and proper outcome of the Velvet Revolution (and the other revolutions in central and eastern Europe) was the establishment of Western-style liberal democracy and socalled free market capitalism. ${ }^{8}$ But this view was not shared by all of the

\footnotetext{
Action: the Motives and Evaluation of Lustration Policy in the Czech Republic and Poland (1989-2001)', Law \& Social Inquiry (2003), pp. 392-410.

$3^{2}$ Quoted in Keane, op. cit., p. 433.

33 'A Witch Hunt in Prague?', New York Times, 6 April 1991. See also Aryeh Neier, 'Watching Rights',

The Nation, 6/13 January 1992, p. 9.

34 Keane, op. cit., p. 435 (recounting information from an interview with Jan Kavan in 1997).

35 Keane, op. cit., pp. 435-436.

${ }^{36}$ As for the lustration law itself, Havel reluctantly signed it and then immediately called for a variety of amendments to mitigate its effects (none of which were passed); see Keane, op. cit., pp. 433-436.

37 See above, footnote 22.

${ }^{38}$ J. C. Isaac, Democracy in Dark Times, Ithaca, Cornell University Press, 1998, pp. 156-158.
} 
actual participants in the events in question, 39 and it was emphatically not the view of Havel himself. This is an important point because the "correctness" or "incorrectness" of Havel's political, moral, and ethical choices vary depending on the observer's point of view. The balance between conviction and responsibility looks very different when Havel's actions are assessed from his own perspective rather than that of his critics. If Havel is judged on the basis of his writings and his actions, he clearly did learn from and adapt to his new situation, modifying or rejecting concepts and behaviours which proved in practice to be counterproductive, however effective they might have been during his life as a dissident.

For example, according to Jan Urban, a prominent member of the Civic Forum movement and a former Charter 77 dissident himself, 'Havel never understood the value of institutions, negotiations, and the need for compromise'; instead, he was 'always about making direct deals, personal compromises, and ... manipulation' ${ }^{40}$ Urban goes on to claim that while these tactics may have been suitable for small, relatively impotent opposition groups, they were completely inappropriate to the practice of politics as president: '[they] most certainly never worked during the first months of his presidency, when power was seen simply as manipulation'.41 This accusation has been repeated from many different quarters. April Carter writes 'that he has been reluctant to address institutional questions and organizational power [and] 'tends to be somewhat imprecise about institutions'.42 Petr Pithart, prime minister of the Czech Republic from early 1990 to mid-1992, argued in 1996 that '[a]s a president with few powers, Havel ought to demonstrate the importance of properly functioning institutions, and of respect for the rules of the game, the constitution, and the legal system'.43 Pithart condemned Havel for what showing what he described as a 'negative attitude toward anything that resembled a party' while Urban disapprovingly commented on Havel's decision to 'declare ... himself a non-partisan President above any political parties'.44 John Keane identifies in Havel a 'hoary prejudice against parliament' and questions whether he 'really wanted to allow the development of a parliamentary democratic system of government'. 45 According to Zdenek Jicinsky, a sometime political opponent of Havel in the early 1990s, Havel's 'limited familiarity with the constitutional relationships in which he was acting' meant that he did not 'respect the institution of parliament'. ${ }^{4}$

To put these criticisms in context, Havel's power as president of Czechoslovakia was distinctly limited. Under the existing (communist) constitution, the president was the country's chief diplomatic representative and the convenor of the Federal Assembly. His signature was required to

\footnotetext{
39 Tucker, op. cit., pp. 162-164, 186-187.

40 Quoted in J. Keane, Vaclav Havel: a Political Tragedy in Six Acts, London, Bloomsbury, 1999, p. 403. The contradiction between claiming that Havel did not understand the need for compromise and then stating that he frequently made 'personal compromises' is neither explained nor clarified.

${ }^{41}$ Ibid.

42 Carter, op. cit., p. 71.

43 V. Havel \& V. Klaus, with commentary by Petr Pithart, 'Civil Society after Communism: Rival Visions', Journal of Democracy Vol.7, No. 1, January 1996, p. 22.

44 Both quoted in Linz \& Stepan, op. cit., pp. 331-332.

45 Keane, op. cit., pp. 422, 419.

${ }^{46}$ Quoted in Ibid., p. 422. To
} 
bring laws into force, he was commander-in-chief of the armed forces, and had the power to appoint and remove the premier and certain other officials. Havel himself saw this as a problem, and as early as 29 June 1990 he proposed to the Federal Assembly 'that the Office of the President should become a "real political office" [where previously] it had offered "a bureaucratic, ceremonial service"'. He specifically mentioned the 'underdeveloped' state of its 'political functions', and suggested that its 'role should be one of ensuring contact between the President ... and other constitutional figures, parliament, the government, political parties, foreign institutions, and Czechoslovak citizens'.47 It is not hard to see how this vision of the role of the president fit with his decision to remain unaffiliated with any political party mentioned above.

Underlying these criticisms is the widespread idea that the construction and strengthening of institutions - and more specifically, Western-style political and economic institutions - is 'the most important single task' to be accomplished in the post-communist period, because it is 'institutions which give [liberty] stability and duration'.48 'Liberal democracy', writes Jeffrey Isaac, 'is the order of the day ... it is impossible to question the attractions of liberal constitutionalism'.49 And if constructing liberal democratic institutions is the most important task at hand, then it logically follows that any action which does not contribute directly to such institution-building is at best a needless distraction and at worst an actual obstacle to the accomplishment of that task.50 If an action can be seen as being disruptive to the construction of western-style structures and institutions, it has been, virtually by definition, considered to be incorrect.

The discomfort felt by many commentators whenever President Havel insisted on addressing moral or ethical issues such as the post-World War II expulsion of the Sudeten Germans, discussed above, was in large part because such actions did not fit the conception that post-communist politicians should be concentrating on institutions, on facts and figures, on interests and politicking - in a word, on "reality". Since by "normal" standards there were no politically valid reasons for Havel as president of Czechoslovakia to even bring up this issue, let alone to suggest that an apology was called for, it was seen as being counterproductive and obstructionist to the presumed goal of constructing institutions. He was not playing his assigned "role" as president. But the idea that this "failure" might be a matter of choice rather than ignorance was not given much attention. But for Havel, nationhood and government involved moral and ethical issues as well as practical ones. Therefore, he felt that it was perfectly rational and indeed necessary to bring up his country's treatment of

\footnotetext{
47 J. Pehe, 'Office of the President Reorganized', 3 August 1990, p. 1, <www.pehe.cz/clanky/1990/19903aAugust1990-RFERL.pdf $>$, accessed on 3 July 2013. Though beyond the scope of this article, it would be interesting to examine Havel's attitudes and actions with regard to the power and role of the presidency through the prism of parliamentary and presidential democratic political systems. Do his attempts to increase the role of the president suggest a preference for a presidential system in which the presidency has a major or even dominant role in the political life of the country? Or, conversely, does his emphasis on morality in cases such as the Sudeten Germans suggest an effort to lift the presidency above party politics and into a more symbolic role, a possibility which necessarily implies the elevation of parliament to the leading role in post-communist Czechoslovakia's nascent democracy?

48 Dahrendorf, op. cit., p. 56.

49 Isaac, op. cit., pp. 156-157.

$5^{\circ}$ Ibid., p. 156.
} 
the Sudeten Germans. He was already hinting at this in his 1990 New Year's Address when he observed that "self-confidence is not pride. Just the contrary: only a person or a nation that is self-confident, in the best sense of the word, is capable of listening to others, accepting them as equals, forgiving its enemies and regretting its own guilt. Let us try to introduce this kind of self-confidence into the life of our community and, as nations, into our behavior on the international stage. Only thus can we restore our self-respect and our respect for one another as well as the respect of other nations. ${ }^{51}$

The point, according to Havel, was to have 'matter-of-fact and utterly unbiased reflection ... to alleviate the consequences of a wretched event.... evil begets evil and ... we too had begun to resettle our nationalities, to ethnically cleanse our country'. ${ }^{2}$

More broadly, the suggestion that Havel either did not comprehend or did not care about the construction of stable, lasting institutions in the Western mould simply does not stand up to an examination of his own writings and speeches. In his New Year's Address to the Nation in 1991, he compiled a list of accomplishments that Czechoslovakia had achieved over the last year; no fewer than five out of nine points concerned the establishment of legitimate, stable institutions and structures in the country: 'the first free elections in forty-two years', the work of the new parliament to 'create the first foundations of a truly legal, democratic and decentralized state', the establishment of 'full freedom of speech and expression ... and freedom of assembly and association', the adoption of 'some significant economic laws, which will form the legal framework for [economic] reform', and the beginnings of 'a true and viable federation', including especially the 'recently adopted constitutional law, which divides executive powers between the two constituent republics and the federation'.53 Several points outlining the tasks for the next year involved similar issues, including the need for 'three new constitutions [at the federal and republic levels] ... which would become a solid and durable basis for our entire new legal order', the dismantling of '[1]arge, inflexible and bureaucratic organizations in the trade and service sector', and the need for a clear strategic conception ... at the government level ... in the social sector, where it is necessary to create promptly ... a safety net of legislative and administrative measures to forestall the unjust and inhumane consequences of economic reform. 54

At the same time, the experiences of Czechoslovakia under communism made it clear to him that institutions as such were not in and of themselves a sufficient basis for a viable democratic system. They were susceptible to abuse and manipulation if they were not connected to considerations of morality, ethics, fairness, and social justice 55 - an idea which is clearly expressed in his call for a safety net to mitigate the negative effects of the needed economic reforms.

\footnotetext{
${ }^{51}$ V. Havel, 1990 New Year's Address to the Nation, op. cit.

$5^{2}$ Havel, To the Castle and Back, op. cit., p. 140.

53 V. Havel, 1991 New Year's Address to the Nation, op. cit. One might also include his reference to Czechoslovakia's 'foreign policy initiatives, aimed at building a new and peaceful Europe'.

54 Ibid.

55 Havel, Summer Meditations, op. cit., pp. 1-20.
} 
Havel's opposition to the lustration bill passed by parliament in October 1991 is another case which demonstrates his willingness to acknowledge the role and power of institutions whilst attempting to temper their power with reason and justice. Havel opposed the lustration law on the grounds that the legislation is based on the principle of collective responsibility ... It prohibits certain persons solely because they belonged to groups defined by their external characteristics. It does not allow their cases to be heard individually. This runs counter to the basic principles of democratic law'.56 $\mathrm{He}$ felt constrained to sign the bill in order to avoid the potential crisis of a confrontation between the presidency and the parliament, but after he had done so, he announced his intention to seek amendments to the legislation in order to remedy its worst defects. 57 His appreciation for the importance of institutions is clear: he acknowledged the right of parliament to pass laws, saw the danger of an open clash between the two branches of government, and worked within his own presidential role to improve the outcome.

Havel did sometimes try to work around institutions, precisely because his appreciation of their uses and importance did not blind him to the potential for abuse that was inherent within them. The clearest example of this was during the period before the so-called "Velvet Divorce" of the Czech Republic and Slovakia during 1992 and 1993. Although the separation has often been described as having been driven by popular demand from the public in the two republics, in actual fact it seems to have been driven more by conflicts between politicians, in particular Vaclav Klaus and Vladimir Meciar, the Czech and Slovak prime ministers respectively. The general public seems to have been overwhelmingly against separation; at the least, it was felt that the question should be decided by a referendum rather than by politicians. 58 Havel, who repeatedly clashed with Klaus throughout the nineties, 59 did his best to bring facilitate public input and influence on the situation by what Tucker disapprovingly describes as "extraparliamentary means;" calling for public demonstrations and presenting bills to parliament which would have allowed for referenda, among other changes to federal law. ${ }^{60}$ To purists, this was an unforgivable sin; for Havel it was simply an attempt to apply morality to the practice of politics. Rather than an attempt to intimidate parliament, as Tucker implies, public demonstrations were a means of encouraging and sustaining direct participation by the citizens ${ }^{61}$ in decisions which profoundly affected them. Simply because parliament had the technical authority to pursue the course towards separation did not make it right for it to do so; especially when the people it was supposedly representing had made it very clear that they did not support that course of action. The only 'constitutional

\footnotetext{
${ }^{56}$ Havel speaking at NYU, 27 October 1991; quoted in Keane, op. cit., p. 434.

57 Ibid., p. 434. See also Stewart \& Stewart, p. 891; Tim McCarthy, 'Growing Up or Selling Out? Czechs Face the Future', Commonweal, 24 September 1993, pp. 14-15.

${ }^{8}$ Linz and Stepan op. cit., pp. 328-330.

59 Keane, op. cit., pp. 441-447.

${ }^{60}$ Tucker, op. cit., p. 191. See also Havel's comments in his 1992 New Year's Address to the Nation, 1 January 1992 (http://old.hrad.cz/president/Havel/speeches/index_uk.html), accessed on 4 February 2013.

${ }^{61}$ Isaac, op. cit., p. 166.
} 
and moral' solution, Havel argued, was to hold a referendum, ${ }^{62}$ a position which remained popular throughout the Czech and Slovak regions of the country even after the June 1992 elections. ${ }^{63}$ It should be noted how this approach to the crisis reflected Havel's views on the role of the presidency as he articulated them in mid-1990, wherein he saw the presidency almost as a sort of ombudsman, maintaining 'contact' amongst the diverse parties involved in Czechoslovak society, including (to list those parties most relevant in this debate) 'the President ... parliament, the government, political parties, ... and Czechoslovak citizens'.64

This is not to argue that those who emphasize the importance of the establishment of stable institutions are incorrect, or that Havel's approach was necessarily correct or even effective. But criticisms of his actions on these grounds are largely based on the assumption that the construction of Western-style institutions was the goal, which should have come before all else. Havel had a different conception of both the value and role of institutions. He did not believe that institutions in the western mould were automatically "accountable ... [and] responsive to claims of justice."65 As a result, he could not and would not give them unquestioning support and attention. They were not the overriding goal of his presidency or, more broadly, of the transition from communism to something else in the aftermath of the Velvet Revolution in Czechoslovakia. Havel opposed what he called 'blind imitation, especially if it becomes an ideology'.66 While he agreed that it made no sense to 'reinvent the wheel' in terms of the basic elements and institutions of national life, he argued that 'this sentiment [can become] a kind of hickory stick to crack across the knuckles of anyone who does not want, for whatever reason, to copy faithfully all the models presented - which today, of course, are western models'.67 Czechoslovakians, he argued, needed to 'find [them]selves anew'; they were looking for 'a new, better and truly just model for [their] existence as a state, and for the coexistence of the nations that live within that state'.68 This process, he said on New Year's Day 1992, was underway: 'parliamentary democracy is beginning to work ... the political spectrum is rapidly crystallizing, and political parties are forming ... The political scene is mercilessly monitored by a free press'.69 But while he was 'delighted that it is happening', he identified problems with the process 'politicking, party squabbles, mutual accusations, malice, and at times even ill will and intrigue' - that are part and parcel of Western political and civil life. He insisted on the need in the somewhat chaotic provisional activity around the technical aspects of building the state' to 'occasionally ... remind ourselves of the meaning of the state, which is, and must remain, truly human', and to remain aware of 'what can happen to even a decent law in the hands of an

62 'Only Moral Solution is Joint Referendum, Havel Tells Citizens', New York Times, 22 June 1992. Constitutionally, as the article notes, 'a split may be approved only through a referendum'; the way around this for those working to divide the country was to resort to Parliament's authority 'to amend the Constitution by a three-fifths majority'.

${ }^{6} 3$ S. Wolchik, 'The Politics of Transition and the Break-Up of Czechoslovakia', in Jiri Musil, (ed.), The

End of Czechoslovakia, Budapest: Central European University Press, 1995, pp. 233-234.

64 Pehe, op. cit., p. 1.

65 Isaac, op. cit., pp. 165-166.

${ }^{66}$ Havel, Summer Meditations, op. cit., p. 124.

67 Ibid, pp. 123-124.

681992 New Year's Address to the Nation, op. cit.

69 Ibid. 
unscrupulous judge, and how easily unscrupulous people can use democratic institutions to introduce dictatorship and terror' ${ }^{70}$

What exactly this 'new, better and truly just model' for the new state might have looked like is unclear. Havel himself devoted an entire chapter entitled 'Beyond the Shock of Freedom' to his vision of a new society in Summer Meditations, but he admitted at the very start that he 'cannot ... leap over the hard years that lie ahead and look into our future', so he could only 'dream for a while'. ${ }^{71}$ It is nevertheless instructive to see what he envisioned. It included 'two large [political] parties with their own traditions ... intellectual potential, clear programs, and ... grassroots support', along with 'several smaller parties'.72 He goes on to outline what he describes as 'a stable Central European democracy that has found its identity and learned to live with itself'.73 The state would be 'highly decentralized', and local rather than national or parliamentary elections and issues would be most important to people. 74 There would be a rich and diverse civil society, with an array of 'local, regional, and state-wide clubs, organizations, and associations with a wide variety of aims and purposes [which] will be so complex that it will difficult to map thoroughly'.75 This is all rather vague and, at least on the surface, not incompatible with the systems which are found in the West, so exactly how Havel hoped Czechoslovakia would be different is open to debate.

\section{Conclusion: Havel's Vision of the Presidency}

Havel and his critics had very different conceptions of his role as president. His critics saw traditional western liberal democracy as not simply a likely or welcome outcome, but as the intended outcome of the revolutions of $1989 .{ }^{76}$ Writing in 1992, Havel defined his role as 'help[ing] this country move from totalitarianism to democracy, from satellitehood to independence, from a centrally directed economy to market economics.' 77 At the same time, he criticized the purists of market economics as suffering from one of the same faults as orthodox Marxists: the certainty that operating from a theory is essentially smarter than operating from a knowledge of life, and that everything that goes against theoretical precepts, that cannot be made to conform to them, or that goes beyond them, is, by definition, worthy only of rejection. 78

This belief of Havel's is crucial for understanding of his behaviour as president of his country. It is not the case that he was trapped in an outdated dissident perspective on the world, unable to adapt to his new environment and the new

\footnotetext{
$7^{0}$ Havel, Summer Meditations, op. cit., p. 19.

${ }^{71}$ Havel, Summer Meditations, op. cit., p.102.

${ }^{72}$ Ibid.

73 Ibid., pp. 102-103.

74 Ibid., p. 103.

75 Ibid., p. 104.

${ }^{76}$ Isaac, op. cit., p. 158. This was not necessarily the opinion of the people of Czechoslovakia themselves. In a poll taken in late November 1989, for instance, $45 \%$ wanted a 'continuation of a socialist path', $47 \%$ 'preferred something between socialism and capitalism', and only $3 \%$ 'wanted to see Czechoslovakia choose a capitalist path of development'. When asked again in early December, the respective numbers were $41 \%, 52 \%$, and $3 \%$. Wolchik, op. cit., pp. 118-119.

77 Havel, Summer Meditations, op. cit., p. xvii.

${ }^{78}$ Ibid., p. 66.
} 
concerns that came with it. Nor is it true that he did not value or wish to see developed stable institutions such as those found in the West. As he noted to the US Congress in early 1990, he was 'speaking ... as the representative of a country which has complete freedom of speech, which is preparing for free elections, and which seeks to establish a prosperous market economy and its own foreign policy' - a description which was hardly a full-throated condemnation of Western-style institutions.79

Havel argued strongly that those things were not sufficient in and of themselves: 80 that institutions established on purely functional grounds, on a devotion to structures, theory, and interests were in a very basic and essential way deficient as a structure for the new, more human - more truthful society which he hoped to see develop in Czechoslovakia after the fall of Communism. He opposed the domination of systems over people, and hoped for something more than an imitation of the West to emerge in Czechoslovakia after $1989 .{ }^{81}$ This is not a concept which is easy to express, though he wrote and spoke about it many times over the years in a continuing effort to clarify his views. It is also not a concept which is popular amongst the politicians and political scientists of the world, who prefer to believe that politics are just about interests, and that "most political questions are technical, questions of means rather than ends, and [that] philosophy has little or nothing to contribute." 82 Vaclav Havel clearly disagreed with that premise. Without understanding that disagreement, the goals towards which Havel worked cannot be properly recognized; without recognizing his goals, it is impossible to correctly interpret his actions.

79 V. Havel, Address to a Joint Session of the US Congress, 21 February 1990,

<http://old.hrad.cz/president/Havel/speeches/index uk.html >, accessed on 4 February 2013.

80 Isaac, op. cit., p. 167.

${ }^{81}$ V. Havel, Open Letters: Selected Prose 1965-1990, London, Faber and Faber, 1991, pp. 267-269.

${ }^{82}$ Tucker, op. cit., p. 7. 